\title{
Pathological and Microbiological Analysis of Cerebrospinal Fluid in Bacterial Meningitis
}

\author{
Ramesh S.T ${ }^{1}$, Girish Babu R. J \\ ${ }^{1}$ Dr Ramesh S T, Associate Professor, Department of Pathology, ${ }^{2}$ Dr Girish Babu R J, Associate Professor, Department \\ of Microbiology, Sri Siddhartha Medical College, B. H. Road, Agalkote, Tumakuru, Karnataka 527107, India.
}

Address for Correspondence: Dr Ramesh S T, Associate Professor, Department of Pathology, Sri Siddhartha Medical College, Agalakote, Tumkur. E -mail: drrameshst@gmail.com

\begin{abstract}
Background: Meningitis is a life threatening infection with incidences increasing in adults and children. CSF analysis is a key tool to diagnose and differentiate between bacterial, viral, tubercular and fungal meningitis. Identifying the causative bacterial organisms is important to guide antimicrobial therapy. Aims \& objectives: The present study was undertaken to analyze CSF parameters and to determine causative organisms of meningeal infection and also to find out their antibiotic susceptibility pattern. Settings and design: Cross sectional study. Methods and Materials: The study includes 100 clinically suspected cases of meningitis. Pathological and Biochemical analysis was done. Bacterial pathogens were identified by conventional methods of culture with sensitivity pattern. Results: Out of 100 cases, 30 cases showed total count $>1000$ cells/ul with neutrophil predominance. 25 cases shows culture growth, with Escherichia coli as predominant organism isolated followed by Streptococcus pneumonia. Imipenem showed 100\% sensitivity followed by Pipercillin/Tazobactum 90\%. Conclusion: Our results of CSF fluid analysis revealed a total count of $>1000$ cells/ul with neutrophil predominance. Escherichia coli was the predominant organism isolated. Imipenem showed $100 \%$ sensitivity.
\end{abstract}

Key words: Meningitis, CSF, Escherichia coli.

\section{Introduction}

Meningitis is an infection of the meninges that surround the brain and the spinal cord. It is usually caused by bacterial, viral or fungal pathogens. Bacterial meningitis is one of the most serious infections seen in all age groups, which is associated with acute complications and chronic morbidity $[1,2]$.

Etiology of bacterial meningitis varies by age group and region of the world. The most common pathogens implicated in the causation of bacterial meningitis are Streptococcus pneumoniae, Neisseria meningitides, Hemophilus influenzae and Escherichia coli [3].

Clinical diagnosis of meningitis is difficult as its early manifestations are often not specific, especially in infants and children due to the immaturity of Central Nervous System in them. Thus laboratory support is imperative to achieve early diagnosis [4].

Manuscript received: $15^{\text {th }}$ September 2016

Reviewed: $27^{\text {th }}$ September 2016

Author Corrected: $10^{\text {th }}$ October 2016

Accepted for Publication: $26^{\text {th }}$ October 2016
CSF analysis includes macroscopic assessment of CSF, microscopic examination for pathologic cells, and biochemical analysis for protein and glucose form the basis for routine CSF analysis. The classic CSF abnormalities in bacterial meningitis are a polymorphonuclear leukocytosis, decreased glucose concentration, and increased protein concentration $[5,6,7]$.

CSF culture is the best diagnostic method and is positive in majority of the cases. Prompt antibiotic sensitivity testing is essential for appropriate treatment $[1,2]$. Since clinical presentation is vague, thus aetiological diagnosis mainly depends on CSF analysis and culture $[3,4]$.

The present study was undertaken to analyze CSF parameters and to determine causative organisms of bacterial meningeal infection and also to find out their antibiotic susceptibility pattern, which will guide the local clinician to treat accordingly. 


\section{Materials and Methods [6,7,8]}

This study on bacterial meningitis was carried out in the Department of Pathology and Microbiology, Sri Siddhartha Medical College and Hospital, Tumkur over a period of one year. A total of 100 cerebrospinal fluid samples obtained from clinically suspected cases of bacterial meningitis of all age groups admitted to the medical and paediatric wards at Sri Siddhartha Medical College and Hospital were included in the study. Meningitis developing following head trauma, neurosurgical procedure, tubercular, anaerobic, viral, fungal, parasitic causes and patients who have received antibiotics for the past one-week from their visit to the hospital were excluded from the study. Informed consent and institutional ethical clearance were obtained.

Sample collection and processing: Cerebrospinal fluid samples received in sterile container to the laboratory was immediately processed. CSF was aliquot into three test tubes. Sample from first test tube was used to analyse total WBC count, cell type. Sample from second test tube was centrifuged at $2000 \mathrm{rpm}$ for 15 minutes and to prevent the possible contamination, the sediment was used first to inoculate the culture media and then direct smear was made by Gram's stain. The third test tube was used for protein and glucose analysis.

Examination of CSF- Macroscopic examination: Appearance of CSF was observed for volume/ turbidity/ purulence and blood staining. Cytological examination: Cell count was done by charging the counting chamber with CSF and counting the leucocytes. A film of centrifuged deposit was examined for differential count and to find out the predominant cell type. Protein and glucose was measured by immunoturbidometry assay using Roche/Hitachi Cobas 311 system with calibrators and internal controls provided by Roche and according to manufactures recommendations.

Culture- For culture and identification, the sediment of the centrifuged CSF was inoculated into the following media: $5 \%$ Sheep blood agar plate, Chocolate agar plate incubated at $37^{\circ} \mathrm{C}$ in $5-10 \% \mathrm{CO}_{2}$ and MacConkey's agar plate incubated at $37^{\circ} \mathrm{C}$. Inoculated primary plates were incubated for 48 hours. Any growth on the above mentioned media was identified on the basis of their colony morphology, cultural characteristics and biochemical reactions according to standard techniques. Antibiotic sensitivity pattern of all the isolates was done by standardized Kirby Bauer's disc diffusion method laid by Clinical and Laboratory Standard Institute (CLSI) guidelines.

Statistical Analysis: Data collected will be entered into Microsoft excel 2007 and analysed using epi info 3.4.3. Descriptive statistics such as proportion will be calculated. Sensitivity analysis will be done to determine the diagnostic accuracy of various investigations.

\section{Results}

In the present study, it was observed that the male were affected more i.e., 62 as compared to 38 females in the ratio of

Table- I: CSF parameters in meningitis

\begin{tabular}{|l|l|}
\hline CSF parameters & Total cases (100) \\
\hline WBCs (total cells /ul ) & 52 \\
\hline$\leq 100$ & 28 \\
\hline$>100-1000$ & 20 \\
\hline$>1000$ & \multicolumn{2}{|l|}{} \\
\hline Cell type : Neutrophils\% & 30 \\
\hline$>50$ & 70 \\
\hline$<50$ & \\
\hline Protein $(\mathbf{m g} / \mathbf{d L})$ & 75 \\
\hline$<50$ & 25 \\
\hline$>50$ & \multicolumn{2}{|l|}{} \\
\hline Glucose $(\mathbf{m g} / \mathbf{d L})$ & 70 \\
\hline$>45$ & 30 \\
\hline$<45$ & \\
\hline
\end{tabular}


1.6:1. The youngest among the case studied was one month old and oldest being 70 yrs. Most common manifestations were fever, vomiting, headache and neck rigidity. Macroscopic appearance of CSF, in 25\% cases shows turbid fluid and $5 \%$ hemorrhagic appearance. In our study, Total WBC count $>1000$ cells /ul were seen in $20 \%$ of cases with neutrophils predominant in $30 \%$ cases. Protein levels $>50 \mathrm{mg} / \mathrm{dl}$ were seen in $25 \%$ of cases, glucose level $<45 \mathrm{mg} / \mathrm{dl}$ were seen in $30 \%$ cases (Table I).

Of the total 100 samples processed, significant growth was found in $25 \%$ samples while $75 \%$ samples showed no growth. The commonest isolated organism being Escherichia coli (32\%) followed by Streptococcus pneumoniae (16\%), Klebsiella pneumoniae (16\%), Group B Streptococci (8\%), Pseudomonas aeruginosa (8\%), Staphylococcus aureus 8\%), Enterococcus faecalis (4\%), Enterobacter aerogenes (4\%), and Citrobacter koseri (4\%). (Table II).

Table No-II- Distribution of Culture Positive Cases According To Spectrum of Bacterial Isolates.

\begin{tabular}{|l|l|l|l|}
\hline Sl No. & Organisms & Total no of cases & Percentage \\
\hline 1 & Escherichia coli & 8 & $32 \%$ \\
\hline 2 & Streptococcus pneumoniae & 4 & $16 \%$ \\
\hline 3 & Klebsiella pneumoniae & 4 & $16 \%$ \\
\hline 4 & Group B Streptococci & 2 & $8 \%$ \\
\hline 5 & Pseudomonas aeruginosa & 2 & $8 \%$ \\
\hline 6 & Staphylococcus aureus & 2 & $8 \%$ \\
\hline 7 & Enterococcus faecalis & 1 & $4 \%$ \\
\hline 8 & Enterobacteraerogenes & 1 & $4 \%$ \\
\hline 9 & Citrobacter koseri & 1 & $4 \%$ \\
\hline Total & & $\mathbf{2 5}$ & $\mathbf{1 0 0 \%}$ \\
\hline
\end{tabular}

Imipenem showed $100 \%$ sensitivity, followed by Pipercillin/Tazobactum 90\%, Co-tirmoxazole $67 \%$ was found to be least sensitive (Table III).

Table No. III- Antibiotic sensitivity pattern of organisms.

\begin{tabular}{|l|l|}
\hline Antibiotic & Percentage \\
\hline Imipenem & $100 \%$ \\
\hline Pipercillin/Tazobactum & $90 \%$ \\
\hline Amikacin & $85 \%$ \\
\hline Cefatazidime/ Clauvnic acid & $85 \%$ \\
\hline Ceftoxime & $75 \%$ \\
\hline Cefatazidime & $77 \%$ \\
\hline Levofloxacin & $80 \%$ \\
\hline Ofloxacin & $77 \%$ \\
\hline Amoxicillin/Clauvnic acid & $72 \%$ \\
\hline Co-tirmoxazole & $67 \%$ \\
\hline
\end{tabular}

\section{Discussion}

Acute bacterial meningitis is a medical emergency, which warrants early diagnosis and aggressive therapy. Despite the availability of potent antibiotics, the mortality rate due to acute bacterial meningitis remains significantly high in India [4]. Most often clinical manifestation are non specific making the role of laboratory support imperative in providing rapid etiologic diagnosis for timely initiation of effective treatment measures [9].
There is a need for periodic review of bacterial meningitis worldwide, since the pathogens responsible for infection vary with time, geography and patient's age. Increase in awareness, availability of vaccines may also reflect a change in the epidemiological pattern of these pathogens. Delay in diagnosis and initiation of treatment can result in poor outcome of the disease [10]. The present study was undertaken to study the pathological and microbiological analysis of CSF in 
Research Article

bacterial meningitis. A total of 100 cases were studied. In the study, highest percentage of bacterial meningitis cases was observed in the age group of 1 months to 2 years. This can be attributed to decreased immunity and high vascularity of the brain in children less than 2 years of age. The increased risk of bacterial meningitis in elderly is multifactorial and includes both a greater propensity for underlying acute and chronic diseases like pneumonia, diabetes, renal or hepatic failure [2].

In the present study, it was observed that the males were affected more compared to females. The common manifestations were fever, vomiting, headache and neck rigidity which correlates with Reyes ER et al. In patients who present with headache, lethargy, vomiting and CNS dysfunction, the likelihood of meningitis must be considered. Fever, seizures and meningeal involvement are the most frequent signs encountered in all age groups regardless of the etiologic organisms isolated on culture [11].

Macroscopic appearance of CSF, in 25\% cases shows turbid fluid and 5\% cases hemorrhagic appearance. Normal CSF is usually clear and colorless like water. CSF turbidity may be caused by increased cell count (WBC leucocytes, erythrocytes, bacteria, fungi and parasites). When blood is present in a CSF specimen, it is necessary to determine whether it is due to a traumatic Lumbar Puncture or intracranial bleeding [12].

Total WBC count $>1000$ cells /ul were seen in $20 \%$ of cases and neutrophils predominance were seen in $30 \%$ cases which were also observed by Reyes et al, Dunbar SA et al and Fouad R et al study $[11,13,14]$.

Lymphocytes and monocytes with occasionally ependymal cells are found in normal CSF. An increased number of neutrophilic granulocytes can be found in bacterial and acute viral CNS infections. In bacterial meningitis cases, CSF shows rise in total WBC count with increase in neutrophil counts $[11,13,14,15]$.

In our study, CSF protein level $>50 \mathrm{mg} / \mathrm{dl}$ with glucose level $<45 \mathrm{mg} / \mathrm{dl}$ were seen in bacterial meningitis which correlates with Abro AH etal. As glucose is actively transported across the blood brain barrier the CSF glucose levels are directly proportionate to the plasma levels. Elevated CSF protein concentration can be found in the majority of patients with Bacterial, Cryptococcal and Tubercular meningitis. Coexistent findings of low sugar level and marked elevation in CSF protein level help distinguish patients with bacterial meningitis from those with viral disease [5, 14,16].

Of the total 100 samples processed, significant growth were found in $25 \%$ samples while $75 \%$ samples showed no growth. The low yield on culture can be attributed to following reasons- delay in transport of specimen to the laboratory, non availability of special media for specific pathogens in the emergency setting, presence of autolysis enzyme in CSF, fastidious nature of pathogen and antibiotic treatment prior to lumbar puncture $[12,17]$.

In our study, commonest isolated organism being Escherichia coli (32\%) followed by Streptococcus pneumoniae (16\%). Meningitis in newborn usually results from an infection of the blood stream. E coli can be transmitted by the mother during pregnancy or labour. Older infants and children usually develop infection through contact with respiratory secretions $[12,17]$.

Culture growth was found in cases were CSF analysis showed rise in total WBC count with neutrophil predominance, along with increase in protein level and decrease in glucose level. A result of CSF analysis with biochemical parameters and culture growth indicates bacterial meningitis. Thus our study correlates with the studies done by Dutt and Kalayadav et al [1, 2].

In the present study, the antimicrobial sensitivity pattern of the isolates shows (100\%) sensitivity for Imipenem followed by Pipercillin/Tazobactum (90\%), and Cotirmoxazole (67\%) was found to be least sensitive [12]. The study observes an increasing resistance pattern among the major pathogens is an alarming sign, the reason could be due to the fact that our hospital is a tertiary care centre to which majority of cases referred are pre-treated with antibiotics. The résistance to different group of drugs can be attributed to the rampant and indiscriminate use of antibiotics leading to the development of large scale drug resistance [12, 3, 18].

Our study has updated information on local causative pathogens and their antibiotic sensitivity pattern which can help the clinicians to formulate the initial empirical therapy.

\section{Conclusion}

Bacterial meningitis remains a major health care problem with incidence rising in adults and children. An early pathological and microbiological analysis and 
providing appropriate antibiotic therapy are life saving and they also reduce chronic morbidity and mortality.

Funding: Nil, Conflict of interest: None initiated, Permission from IRB: Yes

\section{References}

1. Dutt RD, Bhadkaria VK, Dutt C. Pattern and antibiotic susceptibility of bacteria isolated in clinically suspected cases of acute pyogenic meningitis in children in KRH, Gwalior. J. Evolution Med Dent Sci 2014; 3(22):6140-6.

2. Kalayadhav ML. Study of bacterial meningitis in children below 5 years with comparative evaluation of gram staining, culture and bacterial antigen detection. J Clin Diagn Res. 2014 Apr; 8(4): 4-6. doi: 10.7860/ JCDR/2014/6767.4215

3. Modi GB, Patel KD, Soni ST, Patel KJ, Mangukiya JD, Jain PS. Bacteriological profile of pyogenic meningitis in tertiary care hospital, Ahmedabad. 2012; Nat J MED RES 2(3):313-6.

4. Raj SC, Reddy PM, Neelima A. Pattern and antibiogram of bacterial meningitis in children at tertiary care hospital. JSIR 2013; 2(6):1012-6.

5. Abro AH, Abdou AS, Ali H, Ustadi AM, Hasab AAH.Cerebrospinal fluid analysis-acute bacterial versus viral meningitis.PakJMed Sci2008;24(5):645-50.

6. Seehusen DA, Reeves MM, Fomin DA Cerebrospinal fluid analysis. Am Fam Physician. 2003 Sep 15; 68(6):1103-8.

7.T homas V, Ahmed R; Qasim S. Cerebro spinal fluid analysis in childhood bacterial meningitis. Oman Med J. 2008 Jan;23(1):32-3.

8. Clementine YF.Revisiting Cerebrospinal Fluid (CSF) Examination. Laboratory Insights. Proceedings of Singapore Healthcare .Volume 19. Number 4; 2010: 355-9.

9. Mohammadi SF, Patil AB, Nadagir SD, Nandihal N, Lakshminarayana SA. Diagnostic value of latex agglutination test in diagnosis of acute bacterial meningitis. Ann Indian Acad Neurol. 2013 Oct; 16 (4): 645-9. doi: 10.4103/0972-2327.120491.

10 Bhagawati G, Barkataki D, Hazarika NK. Study on isolates of acute meningitis in a tertiary care centre in Assam. Int J Med Public Health 2014; 4:446-50.

11. Reyes ER. Suppurative Bacterial Meningitis: A 6 Year Study. Phil J Microbiol Infect Dis 1986; 73-6.

12. Surinder K, Bineeta K, Megha M. Latex particle agglutination test as an adjunct to the diagnosis of bacterial meningitis. Indian J of Med Microbiol 2007; $25: 395-7$

13. Dunbar SA, Eason RA, Musher DM, Clarridge JE 3rd. Microscopic examination and broth culture of cerebrospinal fluid in diagnosis of meningitis. J Clin Microbiol. 1998 Jun;36(6):1617-20.

14. Fouad R, Khairy M, Fathalah W, Gad T, El-Kholy B, Yosry A. Role of Clinical Presentations and Routine CSF Analysis in the Rapid Diagnosis of Acute Bacterial Meningitis in Cases of Negative Gram Stained Smears. J Trop Med. 2014; 2014:213762. doi: 10.1155/2014/ 213762. Epub 2014 Apr 3.

15. Deisenhammer F, Bartos A, Egg R, Gilhus N, Giovannoni G, Rauer S et al. Routine cerebrospinal fl uid (CSF) analysis. In : Gilhus, Barnes MP, Brainin M editors. European Handbook of Neurological Management: Blackwell Publishing Ltd. 2011; Volume $1(2): 5-17$

16. Mengistu A. Gaeseb J, Uaaka G, Ndjavera C, Kambyambya K, Indongo $\mathrm{L}$ et al. Antimicrobial sensitivity patterns of cerebrospinal fluid (CSF) isolates in Namibia: Implications for empirical antibiotic treatment of meningitis. J Pharma Policy Pract 2013,6; $4: 1-10$

17. Deivanayagam N, Ashok TP, Nedunchelian K, Ahamed SS, Mala N. Bacterial meningitis: diagnosis by latex agglutination test and clinical features. Indian Pediatr 1993;30(4):495-500.

18. Bareja R, Pottathil S, Kumar RS, Singh PG, Ashok VS. Trends in Bacterial etiology amongst cases of Meningitis. J Acad Indus Res 2013;1(12):761-5.

\section{How to cite this article?}

Ramesh S.T, Girish Babu R. J. Pathological and Microbiological Analysis of Cerebrospinal Fluid in Bacterial Meningitis. Trop J Path Micro 2016;2(3):94-98.doi: 10.17511/jopm.2016.i03.03 